\title{
Strategi Pemasaran Pada Rumah Susun BP Batam
}

\author{
Zahra Aqilla Putri Chandra ${ }^{1}$, Maya Ariyanti \\ ${ }^{1}$ Universitas Telkom, zahraaqilla@student.telkomuniversity.ac.id \\ ${ }^{2}$ Universitas Telkom, ariyanti@telkomuniversity.ac.id
}

\begin{abstract}
One of the government agencies that builds and manages flats is BP Batam. BP Batam has flats located in 5 industrial areas in Batam, namely Batu Ampar, Sekupang, Muka Kuning, Tanjung Uncang and Kabil. However, there are still many people who are not interested in living in BP Batam flats. Although the facilities provided are quite complete. The purpose of this study is to provide a marketing strategy for BP Batam in marketing their flats. The method used in this research is descriptive qualitative by using the Forum Group Discussion (FGD) in collecting data. The results of this study indicate that the IFAS Matrix is 2.48 and the EFAS Matrix is 2.76, so that the IE Matrix is in cell 5. Then the marketing strategy should be the SO (StrengthOpportunity) Strategy. The SO (Strength-Opportunity) strategy was chosen because the strength value (1.825) in the IFAS Matrix is greater than the weakness value (0.6625). In addition, the opportunity value (1.717948718) on the EFAS Matrix is also greater than the threat value (1.051282051). The SO (Strength-Opportunity) strategy consists of (1) increasing the offer of temporary housing contracts to industrial workers outside Batam, (2) construct development with evenly distributed facilities/infrastructure, and (3) construct developments that are located spread across Batam.
\end{abstract}

Keywords: External Condition Factors, IE Matrix, Internal Condition Factors, Proposed Marketing Strategy, and TOWS Matrix

\begin{abstract}
ABSTRAK
Salah satu lembaga pemerintah yang membangun dan mengelola rumah susun adalah BP Batam. BP Batam memiliki rumah susun yang berada di 5 kawasan industri di Kota Batam, yaitu Batu Ampar, Sekupang, Muka Kuning, Tanjung Uncang dan Kabil. Namun, masih banyak masyarakat yang belum tertarik untuk menghuni rumah susun BP Batam. Meskipun fasilitas yang disediakan cukup lengkap. Tujuan dari penelitian ini adalah untuk memberikan usulan strategi pemasaran bagi BP Batam dalam memasarkan rumah susun yang mereka miliki. Metode yang digunakan dalam penelitian ini adalah kualitatif deskriptif dengan menggunakan Forum Group Discussion (FGD) dalam mengumpulkan data. Hasil dari penelitian ini menunjukkan bahwa Matriks IFAS sebesar 2,48 dan Matriks EFAS sebesar 2,76, sehingga Matriks IE berada di sel 5. Maka strategi pemasaran yang diambil sebaiknya Strategi SO (Strength-Opportunity). Strategi SO (Strength-Opportunity) dipilih karena nilai kekuatan $(1,825)$ pada Matriks IFAS lebih besar dibandingkan dengan nilai kelemahan $(0,6625)$. Selain itu, nilai peluang $(1,717948718)$ pada Matriks EFAS juga lebih besar dibandingkan dengan nilai ancaman (1,051282051). Strategi SO (Strength-Opportunity) terdiri dari (1) meningkatkan penawaran kontrak hunian sementara kepada pekerja industri luar Batam, (2) pengembangan pembangunan dengan fasilitas/sarana prasarana yang merata, dan (3) pengembangan pembangunan yang letaknya tersebar di Kota Batam.
\end{abstract}

Kata Kunci: Faktor Keadaan Eksternal, Faktor Keadaan Internal, Matriks IE, Matriks TOWS, dan Usulan Strategi Pemasaran

Naskah diterima: 09-06-2021, direvisi: 24-05-2021, diterbitkan: 01-09-2021 


\section{PENDAHULUAN}

Kota Batam sebagai pusat ekonomi dan industri di Kepulauan Riau menjadi daya tarik terhadap arus urbanisasi, kantong-kantong permukiman kumuh yang berada di pusat ekonomi dan di sekitar kawasan industri menjadi tidak terelakan. Disamping itu, dengan rendahnya penghasilan, mereka juga tidak mampu untuk mendapatkan sebuah hunian yang layak menyebabkan bermunculan rumah liar (ruli) (Murtiono et al., 2020).

Rumah liar merupakan rumah yang dibangun tanpa izin dari instansi yang berwenang. Kelompok penghuni rumah liar (ruli) di Kota Batam merupakan Masyarakat Berpenghasilan Rendah (MBR) dan para pekerja industri.

Untuk memenuhi kebutuhan Masyarakat Berpenghasilan Rendah (MBR) dan para pekerja industri akan hunian yang layak, terjangkau, dan sesuai kebutuhan serta mengurangi jumlah rumah liar (ruli) di Kota Batam, maka dibangunlah rumah susun sewa (rusunawa) oleh BP Batam.

Saat ini rumah susun yang dimiliki oleh BP Batam tersebar di 5 lokasi, yaitu Batu Ampar, Sekupang, Muka Kuning, Tanjung Uncang dan Kabil. Dengan total 25 twin blok, rumah susun yang dikelola oleh BP Batam dapat menampung hingga 6.684 orang dengan jumlah kamar 1.833. Rumah susun milik BP Batam ini juga memiliki berbagai fasilitas, seperti:

Tabel 1. Fasilitas Rumah Susun BP Batam

\begin{tabular}{ll}
\hline \multicolumn{1}{c}{$\begin{array}{c}\text { Sarana dan Prasarana } \\
\text { Penunjang }\end{array}$} & \multicolumn{1}{c}{ Fasilitas } \\
\hline Air bersih & $\begin{array}{l}\text { Kamar mandi } \\
\text { dalam }\end{array}$ \\
\hline Listrik PLN & Lemari pakaian \\
\hline Wi-Fi & $\begin{array}{l}\text { Tempat tidur 2 } \\
\text { tingkat }\end{array}$ \\
\hline Kios & Kasur \\
\hline Sarana olahraga & $\begin{array}{l}\text { Air Conditioner } \\
\text { (AC) }\end{array}$ \\
\hline Sarana ibadah & Jemuran pakaian \\
\hline Sarana parkir & Gorden \\
\hline Pengamanan 24 jam & \\
\hline Cleaning service lingkungan & \\
\hline $\begin{array}{l}\text { ATM (hanya rusun Kabil } \\
\text { dan Muka Kuning) }\end{array}$ & \\
\hline Sumber: BP Batam (2019) &
\end{tabular}

BP Batam menyebutkan bahwa penawaran hunian rumah susun kepada masyarakat biasa dilakukan dengan menyebarkan brosur di lingkungan sekitar rumah susun dan lampu merah, pemasangan videotron di dekat bangunan rumah susun, dan pembagian informasi melalui koran elektronik dan juga melalui berita di stasiun televisi area Batam. Seiring berjalannya waktu, terdapat beberapa masalah yang menyebabkan terjadinya penurunan jumlah penghuni rumah susun pada tahun 2017 hingga 2018 .

Untuk menarik kembali antusias masyarakat, khususnya Masyarakat Berpenghasilan Rendah (MBR) dan pekerja industri dalam menghuni rumah susun, maka BP Batam melakukan pembenahan terkait strategi pemasaran rumah susun, perbaikan sarana dan prasana yang rusak, serta meningkatkan layanan rumah susun.

Setelah dilakukan pembenahan rumah susun oleh BP Batam, terjadi peningkatan jumlah penghuni pada tahun 2019. Selain pembenahan yang dilakukan, peningkatan jumlah penghuni juga diakibatkan oleh kemajuan ekonomi dari industri yang ada di Kota Batam. Sehingga pekerja yang sebelumnya pulang ke kampung halaman kembali ke Kota Batam untuk bekerja.

Meski sudah dilakukan pembenahan dan membaiknya keadaan ekonomi di Kota Batam, masih banyak masyarakat yang tidak tertarik untuk menghuni rumah susun BP Batam dan memilih untuk tinggal di rumah liar (ruli). Maka dari itu, perlu adanya penyesuaian strategi pemasaran yang tepat untuk menarik minat masyarakat dalam menempati rumah susun milik BP Batam.

\section{KAJIAN LITERATUR \\ Manajemen Pemasaran}

Manajemen pemasaran merupakan aktivitas dan proses yang terjadi untuk mencapai respons yang diinginkan pihak lawan dengan cara menciptakan, menyampaikan, dan mengomunikasikan nilai pelanggan yang unggul.

\section{Strategi Pemasaran}

Menurut Rangkuti (2016), perumusan strategi pemasaran dilakukan berdasarkan pada analisis menyeluruh terhadap pengaruh 
faktor-faktor lingkungan internal dan eksternal.

\section{Penerapan Strategi Pemasaran}

1. Segmentasi Pasar

Menurut Kotler \& Keller (2016), Segmentasi pasar terdiri dari sekelompok pelanggan yang memiliki kebutuhan dan keinginan yang sama. Terdapat variabel segmentasi utama, yaitu:

a. Segmentasi Geografis

b. Segmentasi Demografis

c. Segmentasi Psikografis

d. Segmentasi Perilaku

2. Targeting

Menurut Kotler \& Keller (2016), setelah perusahaan mengidentifikasi peluang segmen pasarnya, langkah selanjutnya adalah memutuskan berapa banyak dan segmen pasar mana yang akan dibidik atau dipilih.

3. Positioning

Positioning merupakan aktivitas perancangan penawaran dan citra perusahaan kepada konsumen guna memaksimalkan keuntungan bagi perusahaan.

\section{Bauran Pemasaran (Marketing Mix)}

Menurut Perreault et al. (2017), terdapat empat bauran pemasaran (marketing mix), yaitu:

1. Product (Produk), perusahaan mengetahui produk seperti apa yang diinginkan atau dibutuhkan oleh pelanggan.

2. Place (Tempat), perusahaan harus mengetahui tempat untuk menjual produkproduknya.

3. Promotion (Promosi), perusahaan harus mengetahui promosi seperti apa yang diinginkan oleh konsumennya.

4. Price (Harga), perusahaan harus menetapkan harga yang sesuai dengan target pasar dengan memperhatikan jenis persaingan dalam pasar sasaran dan biaya bauran pemasaran secara keseluruhan.

\section{Analisis SWOT}

Dalam mengelola fungsi pemasaran, pemasar harus terlebih dahulu menganalisis mengenai situasi perusahaan dengan menyeluruh. Pemasar perlu melakukan analisis SWOT untuk mengevaluasi keseluruhan perusahaan, seperti kekuatan atau strength (S), kelemahan atau weakness (W), peluang atau opportunity $(\mathrm{O})$, dan ancaman atau threat $(\mathrm{T})$.

\section{Tahapan Perencanaan Strategis}

Menurut Rangkuti (2016), untuk membuat suatu perencanaan strategis yang sesuai, diperlukan penyusunan perencanaan terlebih dahulu. Tahapan penyusunan perencanaan terbagi menjadi tiga tahap, yaitu:

1. Tahap Pengumpulan Data

a. Matriks Faktor Strategi Eksternal

Analisis ini memiliki pengaruh yang sangat kuat, menyebabkan perlunya perhatian lebih terhadap dimensi atau aspek yang terkandung di dalamnya, meskipun berada di luar lingkungan perusahaan (Putri et al., 2018).

b. Matriks Faktor Strategi Internal

Analisis akan dilakukan untuk melihat keadaan perusahaan secara internal, diantaranya seperti, product, price, place, promotion, marketing, finansial (Putri et al., 2018).

c. Matriks Profil Kompetitif

Menurut Nilasari (dalam Hindarwati et al., 2016), matriks profil kompetitif merupakan faktor kunci sukses yang dibandingkan dengan perusahaan pesaing.

2. Tahap Analisis

a. Matriks TOWS

Menurut Kurttila (dalam Sudaryanto, 2016), analisis TOWS adalah sebuah alat yang digunakan untuk menganalisa lingkungan eksternal dan lingkungan internal secara bersama sama untuk memperoleh pendekatan sistematis dan dukungan untuk memperoleh keputusan. Kemudian matriks ini akan menghasilkan empat set kemungkinan strategis yang terdiri dari:

1) Strategi SO, dibuat dengan memanfaatkan seluruh kekuatan perusahaan untuk merebut dan memanfaatkan peluang sebesar-besarnya.

2) Strategi ST, menggunakan kekuatan untuk mengatasi ancaman.

3) Strategi WO, diterapkan berdasarkan pemanfaatan peluang yang ada dengan meminimalkan kelemahan yang ada.

4) Strategi WT, didasarkan pada kegiatan defensif dan berusaha meminimalkan kelemahan yang ada dan menghindari ancaman.

b. Matriks BCG 
Menurut Sudaryanto (2016), Boston Consulting Group (BCG) Matrix merupakan salah satu alat yang digunakan untuk merumuskan strategi pada suatu perusahaan yang memiliki multidivisi dan bersaing pada industri yang berbeda.

\section{c. Matriks General Electric}

Menurut The Association of Business Executives (ABE) \& Training (2008, hal.72), Matriks General Electric memungkinkan adanya penilaian dari pihak perencana dan pertimbangan dalam memperhitungkan sifat pasar dan kemampuan perusahaan.

d. Matriks IE (Internal Eksternal)

Tujuan penggunaan matriks ini untuk memperoleh strategi bisnis tingkat korporat yang lebih detail (Wardoyo, 2018).

e. Matriks SPACE

Matriks SPACE atau dapat juga disebut Matriks Posisi Strategis dan Evaluasi Tindakan, menunjukkan apakah strategi yang paling sesuai untuk organisasi adalah strategi agresif, konservatif, defensif, atau kompetitif (Wardoyo, 2018).

f. Matriks Grand Strategy

Menurut Wardoyo (2018), Matriks Grand Strategy merupakan alat yang populer untuk merumuskan strategi alternatif.

3. Tahap Pengambilan Keputusan

Setelah melakukan pengumpulan data dan menganalisis data, maka selanjutnya dapat dilakukan pengambilan keputusan.

\section{Hak Milik Atas Satuan Rumah Susun}

Besarnya peningkatan jumlah penduduk mengakibatkan meningkatnya jumlah kebutuhan akan hunian yang layak. Selama ini pemenuhan kebutuhan akan hunian dilakukan dengan pembangunan horizontal. Hal ini menyebabkan persediaan tanah, khususnya di perkotaan menjadi sangat terbatas.maka dari itu pembangunan hunian di wilayah perkotaan ditempuh dengan pembangunan rumah susun (Santoso, 2017, hal. 213).

\section{METODE PENELITIAN}

Penelitian yang dilakukan oleh peneliti termasuk penelitian deskriptif. Hal ini dikarenakan peneliti memiliki detail informasi dari objek yang diteliti sehingga peneliti sudah mampu membuat pertanyaan penelitian yang jelas. Metodologi penelitian termasuk ke dalam metodologi penelitian kualitatif. Sebab, peneliti hanya melibatkan analisis data berupa deskripsi. Selain itu, peneliti juga menerapkan Forum Group Discussion (FGD) dengan mengambil unit analisis berupa perusahaan, yaitu BP Batam dan rumah susun yang mereka kelola untuk mendapatkan informasi yang dibutuhkan dalam melakukan penelitian.

Dalam penelitian ini, peneliti memiliki lima tahapan, yaitu:

1. Memulai penelitian, dalam tahap ini peneliti mencari permasalahan dan merumuskan masalah.

2. Melakukan studi literatur, dalam tahap ini peneliti mencari data yang dapat mendukung penelitian dengan memanfaatkan artikel, buku, dan penelitian terdahulu.

3. Melakukan Forum Group Discussion (FGD) bersama beberapa narasumber, yaitu Kepala Bagian Layanan Pengadaan Barang dan Jasa, Manajer Komersil, Manajer Operasional dan Pemeliharaan, Asisten Manajer Pemasaran, dan Staff HGAT (Hunian, Gedung, Agribisnis, dan Taman) BP Batam. Forum Group Discussion (FGD) dilakukan untuk menganalisis lingkungan internal dan eksternal, STP (Segmentasi, Targeting, dan Positioning), dan bauran pemasaran rumah susun BP Batam yang akan mendukung penelitian.

4. Melakukan analisis penelitian, dimana peneliti melakukan analisis penelitian berdasarkan data-data yang sudah dikumpulkan.

5. Membuat kesimpulan penelitian. Peneliti mengambil kesimpulan penelitian berdasarkan hasil analisis yang sudah dilakukan.

\section{PEMBAHASAN}

\section{Keadaan Faktor Internal Pada Rumah Susun BP Batam}

1. Kekuatan

Hasil Forum Group Discussion (FGD) menunjukkan bahwa terdapat berbagai kekuatan yang dimiliki rumah susun BP Batam yang terdiri dari:

a. Frekuensi Penawaran yang Tinggi

Dalam memasarkan rumah susun, BP Batam melakukan komunikasi dengan pengelola usaha di Kota Batam. Sehingga 
pengelola usaha dapat memenuhi kebutuhan pekerja akan tempat tinggal yang layak. Selain itu, BP Batam juga memanfaatkan videotron untuk menampilkan gambar rumah susun berbentuk digital.

b. Fasilitas dan Sarana/Prasarana yang Lengkap

Rumah susun BP Batam memiliki berbagai fasilitas dan sarana/prasarana yang dapat menunjang aktivitas penghuninya.

c. Struktur Bangunan yang Baik

Meskipun bangunan rumah susun BP Batam sudah berumur (hampir 20 tahun), namun struktur bangunan masih sangat baik.

d. Struktur Pengelolaan Rumah Susun yang Baik

Baiknya pengelolaan rumah susun $\mathrm{BP}$ Batam menjadikannya sebagai rumah susun terbaik di Kota Batam. Rumah susun BP Batam juga dijadikan sebagai rumah susun percontohan oleh Perusahaan Umum Pembangunan Perumahan Nasional (Perumnas).

e. Letaknya Tersebar di Kota Batam

Rumah susun BP Batam terletak di seluruh kawasan industri yang ada di Kota Batam. Sehingga dapat menjangkau seluruh pekerja industri yang ada di Kota Batam.

2. Kelemahan

Kelemahan rumah susun BP Batam seperti:

a. Jumlah SDM Kurang

Jumlah SDM yang sesuai sangat dibutuhkan dalam pengelolaan rumah susun. Agar pengelolaan rumah susun lebih baik kedepannya.

b. SDM Kurang Kompeten

Akibat kurangnya jumlah SDM, menyebabkan banyak SDM kurang kompeten dalam mengelola rumah susun. Sehingga dapat menurunkan efektifitas kinerja karena kurangnya pengetahuan dan keterampilan.

c. Terikat dengan PERKA

PERKA (Peraturan Kepala) merupakan peraturan yang dikeluarkan oleh seseorang yang menduduki jabatan tertinggi dalam suatu instansi, dalam hal ini Kepala BP Batam. Sehingga untuk mengubah suatu peraturan atau ketentuan yang ditetapkan memerlukan proses yang panjang dengan durasi yang lama.

d. Lemahnya Birokrasi

Pengelolaan birokrasi rumah susun memiliki kendali yang terbatas.

e. Anggaran Kurang

Dalam mengelola rumah susun, BP Batam kekurangan anggaran yang menjadi salah satu penghambat perkembangan rumah susun.

3. Matriks IFAS (Strategi Faktor Internal)

Setelah mengetahui berbagai peluang dan ancaman atau keadaan faktor internal rumah susun BP Batam, maka selanjutnya dirumuskan kedalam Matriks IFAS pada Tabel 2.

\section{Keadaan Faktor Eksternal Pada Rumah Susun BP Batam}

\section{Peluang}

Hasil Forum Group Discussion (FGD) menunjukkan bahwa terdapat berbagai peluang yang dapat dicapai oleh rumah susun BP Batam yang terdiri dari:

a. Kontrak Hunian Sementara

Kontrak ini ditujukan pada pekerja yang berasal dari luar Kota Batam yang ingin menginap di hunian hanya dalam waktu yang singat (kurang dari 6 bulan). Dengan adanya sistem ini, maka pendapatan rumah susun juga akan meningkat.

b. Pengembangan Usaha

Kedepannya, BP Batam ingin mengembangkan usaha lain yang dapat meningkatkan transaksi harian. Setelah diadakan observasi dan survei oleh BP Batam, hasilnya jumlah transaksi harian yang berada di area rumah susun BP Batam sangat besar.

c. Peningkatan Pariwasata

Dengan meningkatkan potensi pariwisata, Kota Batam dapat meningkatkan minat wisatawan untuk berkunjung ke Kota Batam.

d. Revitalisasi

Revitalisasi merupakan cara untuk menghidupkan atau memberdayakan kembali sesuatu yang penting. Revitalisasi hunian menjadi prioritas karena besarnya sumber pendapatan yang didapatkan.

e. Kebijakan Pemerintah

Melalui kawasan ekonomi khusus, Kota Batam dapat meningkatkan penanaman 
investasi yang dapat meningkatkan kegiatan ekonomi.

f. Pengembangan Pembangunan

Peluang pengembangan dilakukan mengingat akan berkembangnya kawasan industri elektronik dan industri maritim di Kota Batam.

2. Ancaman

Selain peluang, ada pula beberapa ancaman yang muncul dari lingkungan eksternal seperti:

a. Penyewaan Hunian oleh Masyarakat Sekitar Rumah Susun

Kota Batam memiliki banyak pengelola rumah susun, seperti Pemerintah Kota, Jamsostek, dan Perumnas. Jika mereka melakukan inovasi berupa penurunan harga sewa rumah susun dan meningkatkan fasilitas rumah susun, maka ini dapat menjadi tantangan besar bagi pemasaran rumah susun BP Batam.

b. Kondisi Saat Ini

Pandemi menjadi ancaman sekaligus tantangan karena tidak dapat diprediksi waktu berakhirnya.

c. Tingkat Industri Negara Lain

Kawasan industri besar bukan hanya berada di Indonesia, tetapi juga Vietnam, Thailand, China, Malaysia, dan negaranegara lainnya. WNI lebih tertarik untuk bekerja di negara-negara tersebut dibandingkan di Indonesia, khususnya Batam. Sebab, banyak kelebihan yang membuat mereka tertarik untuk bekerja di luar negeri.

3. Matriks EFAS (Strategi Faktor Eksternal)

Setelah mengetahui berbagai peluang dan ancaman atau keadaan faktor eksternal rumah susun BP Batam, maka selanjutnya dirumuskan kedalam Matriks EFAS pada Tabel 3.

\section{Usulan Strategi Pemasaran Pada Rumah Susun BP Batam}

\section{Matriks IE (Internal Eksternal)}

Matriks ini terdiri dari sembilan sel yang terbagi menjadi garis vertikal dan garis horizontal. Garis horizontal didapatkan dari total skor pada Matriks IFAS dan garis vertikal didapat dari total skor pada Matriks EFAS. Dimana total skor Matriks IFAS sebesar 2,48 dan total skor pada Matriks EFAS sebesar 2,76. Sehingga posisi rumah susun BP Batam pada Matriks IE berada di sel 5.

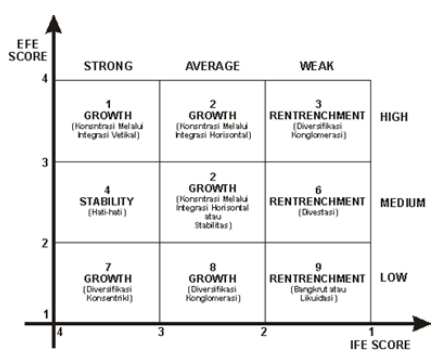

Sumber: Rangkuti (2016)

\section{Gambar 1. Matriks IE}

Dalam penelitian Sari \& Oktafianto (2017) serta Mahfud \& Mulyani (2017), objek penelitian juga termasuk kedalam sel 5 . Mahfud \& Mulyani (2017) menyebutkan bahwa perusahaan yang termasuk dalam sel 5 memiliki kemampuan internal dan eksternal sedang. Dalam kedua penelitian tersebut, disebutkan bahwa strategi pemasaran dapat dilakukan dengan penetrasi pasar (pengembangan pasar dan pengembangan produk).

\section{Matriks TOWS}

Dalam penelitian ini, peneliti juga menggunakan Matriks TOWS atau Matriks SWOT. Dengan menggunakan matriks ini, peneliti dapat menemukan empat kemungkinan strategi dalam menarik minat masyarakat untuk menempati rumah susun BP Batam. Sehingga empat kemungkinan strategi yang dihasilkan pada Tabel 4 .

3. Segmentasi, Targeting, dan Positioning

Setelah mengetahui posisi perusahaan pada Matriks IE dan mengetahui usulan strategi pemasaran pada Matriks TOWS, maka langkah selanjutnya adalah menganalisis segmentasi, targeting, dan positioning. Analisis ini perlu dilakukan sehingga kita mengetahui pelanggan seperti apa yang ditargetkan sebelum usulan strategi pemasaran diterapkan.

Dalam memasarkan rumah susun BP Batam, penerapan segmentasi, targeting, dan positioning yang dilakukan hingga saat ini, yaitu:

a. Segmentasi

Dalam memasarkan rumah susun, BP Batam memiliki klasifikasi segmentasi, yaitu: 
1) Segmentasi Geografis, rumah susun $B P$ Batam mensegmentasikan pasarnya kedalam kawasan industri.

2) Segmentasi Demografis, rumah susun BP Batam mensegmentasikan pasarnya dengan pekerjaan sebagai pekerja industri, pekerja kantor, dan Masyarakat Berpenghasilan Rendah (MBR) yang berasal dari semua kalangan dan ukuran keluarga.

3) Segmentasi Psikografis, rumah susun BP Batam tidak memiliki klasifikasi khusus.

b. Targeting

Rumah susun BP Batam menargetkan pekerja industri menengah atas untuk menghuni rumah susun.

c. Positioning

Rumah susun BP Batam memposisikan dirinya sebagai rumah susun terbaik di Kota Batam. Hal ini digambarkan melalui lengkapnya fasilitas dan sarana/prasarana, kawasan yang bersih, teratur, dan pegawai yang sigap.

4. Bauran Pemasaran (Marketing Mix)

Setelah mengetahui segmentasi, targeting, dan positioning, perlu dianalisis bauran pemasaran yang diterapkan oleh rumah susun BP Batam hingga saat ini. Analisis bauran pemasaran perlu dilakukan agar usulan strategi pemasaran yang dirumuskan menjadi lebih matang.

Dalam memasarkan rumah susun BP Batam, penerapan bauran pemasaran (marketing mix) yang dilakukan hingga saat ini, yaitu:

a. Product (Produk)

Berdasarkan kuesioner yang disebarkan oleh pengelola rumah susun BP Batam kepada penghuni, didapatkan hasil bahwa fasilitas yang tersedia di rumah susun saat ini sudah sesuai dengan keinginan konsumen.

b. Place (Tempat)

BP Batam bekerjasama dengan Event Organizer dari KADIN (Kamar Dagang dan Industri Indonesia) sebagai pihak ketiga untuk memasarkan rumah susun.

c. Promotion (Promosi)

BP Batam memanfaatkan brosur, radio, mall, koran, Instagram, dan berita di televisi dalam memasarkan rumah susun. BP Batam juga memanfaatkan penjualan melalui word of mouth dan videotron yang dipasang di sejumlah titik srategis di Kota Batam.

d. Price (Harga)

Harga sewa rumah susun BP Batam bervariatif, tergantung pada lokasi rumah susun juga letak kamar yang disewa. Harga yang ditetapkan oleh rumah susun BP Batam telah ditetapkan di dalam PERKA (Peraturan Kepala) BP Batam. Harga ini menimbulkan berbagai reaksi, salah satunya masyarakat yang menganggap bahwa rumah susun mahal.

\section{SIMPULAN}

Berdasarkan pembahasan yang telah diuraikan sebelumnya, maka kesimpulan dari hasil analisis strategi pemasaran pada rumah susun BP Batam, yaitu: Faktor internal pada rumah susun BP Batam terbagi menjadi kekuatan dan kelemahan. Kekuatan tersebut terdiri dari frekuensi penawaran yang tinggi, fasilitas dan sarana/prasarana yang lengkap, struktur bangunan yang baik, struktur pengelolaan yang baik, dan letaknya yang tersebar di Kota Batam. Sedangkan kelemahan pada rumah susun BP Batam terdiri dari jumlah SDM yang kurang, SDM kurang kompeten, terikat dengan PERKA, lemahnya birokrasi, dan anggaran yang kurang. Dari faktor internal tersebut, peneliti merumuskannya kedalam Matriks IFAS dengan total keseluruhan sebesar 2,4875 atau sebesar 2,48. Faktor eksternal pada rumah susun BP Batam terbagi menjadi peluang dan ancaman. Peluang tersebut terdiri dari kontrak hunian sementara, pengembangan usaha, peningkatan pariwisata, revitalisasi, kebijakan pemerintah, dan pengembangan pembangunan. Sedangkan ancaman pada rumah susun BP Batam terdiri dari penyewaan hunian oleh masyarakat sekitar rumah susun, tingkat pertumbuhan ekonomi, kebijakan pemerintah, adanya inovasi dari pengelola rumah susun lainnya, kondisi saat ini, dan tingkat industri negara lain. Dari faktor eksternal tersebut, peneliti merumuskannya kedalam Matriks EFAS dengan total keseluruhan sebesar 2,769230769 atau 2,76. Berdasarkan strategi pemasaran (segmentasi, targeting, positioning, dan bauran pemasaran) yang telah diterapkan saat ini, serta faktorfaktor internal dan eksternal yang 
mempengaruhi rumah susun BP Batam, maka usulan strategi pemasaran yang diambil sebaiknya strategi SO (Strength-Opportunity) dari Matriks TOWS. Strategi SO (StrengthOpportunity) dipilih karena nilai kekuatan $(1,825)$ pada Matriks IFAS lebih besar dibandingkan dengan nilai kelemahan $(0,6625)$. Selain itu, nilai peluang $(1,717948718)$ pada Matriks EFAS juga lebih besar dibandingkan dengan nilai ancaman $(1,051282051)$. Strategi SO (StrengthOpportunity) terdiri dari: Meningkatkan penawaran kontrak hunian sementara kepada pekerja industri luar Batam. Pengembangan pembangunan dengan fasilitas/sarana prasarana yang merata. Pengembangan pembangunan yang letaknya tersebar di Kota Batam.

\section{REFERENSI}

Hindarwati, E. N., Yuniarty, \& Farah, Y. (2016). Analisis Strategi Bisnis Pada PT Datacomm Diangraha. Jurnal Ekonomi Manajemen Dan Perbankan, 2(3), 8998.

http://dx.doi.org/10.35384/jemp.v2i3.10 7

Kotler, P., \& Keller, K. L. (2016). Marketing Management (S. Wall (ed.); 15th ed.). Pearson Education.

Mahfud, T., \& Mulyani, Y. (2017). Aplikasi Metode QSPM ( Quantitative Strategic Planning Matrix ). Jurnal Sosisal Humanioradan Pendidikan, 1(1), 66-76. https://doi.org/https://doi.org/10.32487/j shp.v1i1.240

Murtiono, H., Sari, S. R., Pandelaki, E. E., Studi, P., Arsitektur, M., \& Semarang, U. D. (2020). Peran Hunian Vertikal Sebagai Solusi Terhadap Kawasan Kumuh Di Kota Batam Kepulauan Riau. ARCADE Jurnal Arsitektur, 47-51. https://doi.org/https://doi.org/10.31848/a rcade.v4i1.326

Perreault, W. D., Cannon, J. P., \& McCarthy, E. J. (2017). Essentials of Marketing (S. Gouijnstook (ed.); 15th ed.). McGraw Hill Education.
Putri, R. R. S. P., Sudono, A., \& Handyastuti, I. (2018). Strategi Pengembangan Bisnis di Rumah Makan Batagor Baso Citamiang Spesial Bandung. Gastronomy Tourism Journal, 4(2), 2228. http://repository.upi.edu/

Rangkuti, F. (2016). Teknik Membedah Kasus Bisnis Analisis SWOT (P. Lubis (ed.); 22nd ed.). PT Gramedia.

Santoso, U. (2017). Hak Atas Tanah, Hak Pengelolaan, \& Hak Milik Atas Satuan Rumah Susun (I. Fahmi \& Suwito (eds.); 1 st ed.). Kencana.

Sari, D. P., \& Oktafianto, A. (2017). Penentuan Strategi Bisnis Menggunakan Analisis Swot Dan Matriks Ifas - Efas Pada Cv. Dinasty. Seminar Nasional IENACO, 238-245.

https://publikasiilmiah.ums.ac.id/handle/ $11617 / 8671$

Sudaryanto, R., \& Karningsih, P. D. (2016). Integrasi TOWS, AHP dan SAW dalam Perumusan Strategi (Studi Kasus PT. "XYZ"). Jurnal Studi Manajemen Dan Bisnis, 3 Nomor 2. https://doi.org/https://doi.org/10.21107/j smb.v3i2.2623

The Association of Business Executives (ABE), \& Training, R. B. (2008). Strategic Marketing Management. 44(0), 464.

Wardoyo, G. Y. (2018). Aplikasi Matrik Strategi Dalam Perencanaan Strategi Perusahaan. MATRIK (Jurnal Manajemen Dan Teknik), 10(2), 59. https://doi.org/10.30587/matrik.v10i2.37 9 